\title{
The Appropriateness of Using Aquatic Snails as Bioindicators of Toxicity for Oil Sands Process-Affected Water
}

\author{
Zhongzhi Chen *D, Brian Eaton and Jim Davies \\ InnoTech Alberta, Vegreville, AB T9C 1T4, Canada; brian.eaton@innotechalberta.ca (B.E.); \\ jim.davies@innotechalberta.ca (J.D.) \\ * Correspondence: zhongzhi.chen@innotechalberta.ca; Tel.: +1-780-208-0371
}

\begin{abstract}
Canada's oil sands mining activity produces large volumes of oil sands process-affected water (OSPW), and there have been increasing concerns regarding the potential environmental impacts associated with this material. Developing an understanding of the toxicity of OSPW is critical to anticipating and mitigating the potential risks and effects of the oil sands industry on surrounding ecosystems. The composition of OSPW is highly variable and is influenced by a range of factors. While numerous research projects have been conducted on the toxicity of OSPW, much remains unknown about its impact on various biota. Freshwater gastropods (snails and slugs) are an ecologically crucial aquatic group, and members of this taxa have been used as bioindicators in a range of ecological settings. The literature suggests freshwater snails could be used as an indicator of toxicity in monitoring programs associated with oil sands development. This mini-review explores the use of snails as bioindicators in aquatic systems affected by oil sands development, focusing on how snails may respond to potential constituents of concern in systems exposed to OSPW.
\end{abstract}

Keywords: snail (aquatic/freshwater); bioindicator; toxicity effects; oil sands; process water; OSPW

Citation: Chen, Z.; Eaton, B.; Davies, J. The Appropriateness of Using Aquatic Snails as Bioindicators of Toxicity for Oil Sands Process-Affected Water. Pollutants 2021, 1, 10-17. https://doi.org/ 10.3390/pollutants1010002

Received: 3 December 2020 Accepted: 28 December 2020 Published: 6 January 2021

Publisher's Note: MDPI stays neutral with regard to jurisdictional clai$\mathrm{ms}$ in published maps and institutional affiliations.

Copyright: (C) 2021 by the authors. Licensee MDPI, Basel, Switzerland. This article is an open access article distributed under the terms and conditions of the Creative Commons Attribution (CC BY) license (https:// creativecommons.org/licenses/by/ $4.0 /)$.

\section{Introduction}

Oil sands process-affected water (OSPW) is a term used to denote those waters whose composition has been altered by bitumen extraction or material transport processes [1] OSPW is produced in considerable quantities by the oil sands industry [2] and represents a complex mixture of chemical compounds and elements. Several substances in OSPW, including naphthenic acids (NAs), polycyclic aromatic hydrocarbons (PAHs), metals, and ions [3], may contribute to acute and chronic toxicity in aquatic environments. Although no releases of any OSPW into the aquatic environment have been approved to date, seepage from tailing ponds is still an ongoing concern [4]. Considering the increasing inventories of OSPW from the oil sands industry, sustainable water management practices may require returning treated water to the environment, even in the short-term [5]. Therefore, it is important to determine the potential environmental impact of OSPW on aquatic systems in the oil sands region to inform better risk assessment and management practices related to oil sands extraction and processing [6]. While the specific toxicological effects of OSPW on aquatic organisms are not well understood [7], it is possible that a bioindicator approach may be used to address environmental concerns associated with oil sands development. Bioindicator species can effectively reflect the nature and/or magnitude of environmental changes [8]. Bioindicators can be used to monitor the overall adverse effects of OSPW without needing to know the combined impacts of individual components and how they interact (e.g., synergetic or antagonistic), though it can be challenging to select and identify appropriate bioindicators based on their sensitivity to individual constituents of concern [9].

Freshwater gastropods (Mollusca: Gastropoda; snails and slugs) are broadly distributed in various aquatic environments and represent significant biomass in freshwater ecosystems, such as small streams and springs [10]. Snails are crucial to many food webs, both as decomposers and as consumers [11]. Freshwater snails are regularly utilized as 
ecotoxicological models for laboratory and in situ studies [12] since they can be easily accommodated within relatively little space and are easy to manipulate/breed [13]. In addition, freshwater snails have a relatively short life cycle, which minimizes the time required to complete testing procedures. For example, the great or common pond snail (Lymnaea stagnalis), has a lifespan of only 2 to 2.5 years. The objective of this mini-review is to explore the potential utility of snails as bioindicators of OSPW toxicity.

\section{Bioindicator}

Ecotoxicological bioindicators can warn of potential impacts to the survival of individual species and act as part of an early warning system [14]. The risk associated with OSPW, because it is a complex mixture, cannot be adequately evaluated using those toxicity tests traditionally employed for risk assessment [15]. The compositional complexity of OSPW, combined with the high cost associated with traditional toxicity assays, suggests the utilization of bioindicators as a means of assessing ecological status. Bioindicators can also be combined with other assessments of toxicity (e.g., rainbow trout toxicity assays) to estimate the risks of OSPW to freshwater ecosystems. For example, potential bioindicators could be incorporated into ecotoxicological analysis for water quality assessment.

A bioindicator is any living organism or community that reflects an important characteristic of the surrounding environment [16]. Bioindicators are an essential tool for detecting the environmental impact of industrial processes and materials [17]. A highquality bioindicator should satisfy specific criteria, including a well-characterized biology, the ability to generate an early warning of impact to ecosystem health, wide distribution in the relevant environment, embodiment of an essential function in the ecosystem, and the presence of a well-established link between the toxicological endpoint and the level of a pollutant [18]. By these criteria, some aquatic snails have the potential to be considered ideal bioindicators. For example, the biology of a few snail species, such as Biomphalaria glabrata [19], are well-studied. Some species are known to respond to environmental contaminants; for example, esterase activity of Lymnaea natalensis is considered an early warning signal of pollutants exposure [20]. The relationship between the degree of metal exposure and a measurable effect has been largely established for some freshwater snails, such as Biomphalaria alexandrina [21] and Pomacea canaliculate [22]. Mollusks have been recognized as ideal bioindicators for decades [23], and snails, which are widespread in freshwater ecosystems, can represent up to $60 \%$ of the total biomass of macroinvertebrates in some freshwater ecosystems [24].

Several ecotoxicological studies have been reported which used freshwater snail species as bioindicators [25]. For instance, Lymnaea stagnalis has been widely adopted in ecotoxicological studies and pollution biomonitoring programs [26], especially for investigating the toxicological effects of aquatic contaminants [27]. Some relevant studies using freshwater snails in ecotoxicological assessments of analytes relevant to OSPW are provided in Table 1. Interestingly, more investigations focus on potentially toxic metals than organic compounds, perhaps due to the technical challenges associated with the quantification and characterization of organic materials.

The sensitivity of aquatic invertebrates to OSPW has been reported to be between that of fish and macrophytes [28]. A recent species sensitivity distribution comparisonexpressed as critical target lipid body burdens (CTLBBs) - was developed for organisms exposed to OSPW-related organics [29]. The results showed that the relative species sensitivity of Lymnaea stagnalis ( $\log$ CTLBB $=1.83 \mu \mathrm{mol} / \mathrm{g}$ lipid) is close to the mean of 14 tested aquatic species (log CTLBBs $=1.85 \mu \mathrm{mol} / \mathrm{g}$ lipid), including invertebrates, algae, and bacteria [30]. A biomimetic extraction method by solid-phase microextraction (BE-SPME) has been developed to predict toxicity during exposure to complex organic mixtures [31]. Pairing BE-SPME analysis results with toxicity response/endpoints of snails could validate this screening tool for estimating the toxicity of OSPW in the future. 


\section{Effect of Naphthenic Acids}

NAs refer to an extensive and diverse group of polar organic compounds present in OSPW [32]. Reviews of the composition and toxicity of OSPW have confirmed NAs as the primary source of toxicity (both acute and chronic) to a variety of fish and invertebrates [33]; it is possible that this toxicity can be alleviated through the process of biodegradation [34].

Research on the toxicity of commercial NAs to the pond snail, Physa heterostropha, can be traced back to the 1960s [35], and investigations of the adverse impact of NAs on the physiological and behavioral functions of snails (e.g., Lymnaea stagnalis [36]) are still ongoing. Recently, the embryonic development of Lymnaea stagnalis has emerged as a tool in the study of toxicity associated with NAs derived from OSPW [37]. Although reported EC50 (concentration associated with $50 \%$ effect, $31 \mathrm{mg} / \mathrm{L}$ ) for NAs (solution $\mathrm{pH}$ 7.2-7.6) in Lymnaea stagnalis is higher than in fathead minnow (Pimephales promelas $1.7-12.4 \mathrm{mg} / \mathrm{L}$ for hatching success, solution $\mathrm{pH} 8.2-8.4$ [38]), this snail species was suggested as a bioindicator to monitor the acute toxicity of surfactants in aquatic ecosystems [39]. This point is especially pertinent to the effects of OSPW, given that the mechanism of toxicity for NAs may be associated with their surfactant properties [40]. The age of OSPW, as well as the character of the oil sands materials with which it has been in contact are important determinants of its NA molecular structure [41]. The analytical difficulties associated with NAs [42], as well as the qualitative differences between commercially available and OSPW-extracted NA mixtures [43], are still challenges for the quantification and comparison of toxicity data between species.

\section{Accumulation of Polycyclic Aromatic Hydrocarbons (PAHs)}

PAHs are a concern in the oil sands area of Alberta [44]. Mortality was not detected in the freshwater snail, Physella virgata, subsequent to acute exposure to a fluoranthene (a PAH) within the limit of its water solubility [45]. However, subsequent investigations of PAH toxicity in the Lymnaeidae family suggested that these freshwater snails may be useful bioindicators for this class of compounds [46]. Recently, the freshwater snail Lanistes carinatus was reported as a bioindicator for crude oil pollution based on its capacity to bioaccumulate PAHs [47]. The biota sediment accumulation factor (BSAF) values observed in field-collected freshwater brown snails in Nigeria ranged between 0.22 and 11.72 among 12 individual PAH compounds [48].

\section{Effect of Other Organic Compounds}

Other organic compounds found in the oil sands environment include BTEX (benzene, toluene, ethylbenzene, xylenes) and their alcohol derivatives such as phenol [49]. To the authors' best knowledge, fewer studies have been conducted on organic compounds than on metals and other trace elements. The effects of benzene, xylene, and styrene on the mortality of Amphimelania holandri and Lymnaea stagnalis have been explored, but it was found that freshwater snails were less sensitive to these compounds than certain crustacean species are [50]. Ethylbenzene was believed to be the source of potential genotoxicity in the freshwater snail Bellamya aeruginosa [51], but further evaluation is required to confirm this supposition.

\section{Bioaccumulation of Metals}

Metals exist as free cations or as inorganic/organic complexes in water and do not degrade like organic compounds. Many metals have the potential for bioaccumulation and biomagnification in aquatic organisms [52] and studies of the ability of snails to bioaccumulate metals have been reported for years [53]. For example, it was reported in the 1970s that Physa gyrina can rapidly accumulate cadmium (Cd) [54]. Over the past two decades, toxicological investigations involving freshwater snails have focused on sensitivity to metals [27]. Pulmonated (i.e., air breathing) freshwater snails are sensitive to both acute and chronic metals exposures [55], which makes these taxa particularly relevant as bioindicators informing future water quality criteria [56] and metals risk assessments [57]. 
Several species of freshwater snails, including Viviparus acerosus [58], Lymnaea stagnalis [59], and Physa acuta [60], have great potential to serve as bioindicators of metal pollution. For example, Physa acuta was shown to be a suitable bioindicator of metal toxicity under laboratory conditions [61]. Subsequent research has confirmed this species to be useful for metal bio-uptake research [62]. In addition, Lymnaea stagnalis was reported to be one of the most sensitive species to a $96 \mathrm{~h}$ copper exposure [53], and a good bioindicator of mercury contamination in aquatic ecosystems [63]. A recent study revealed that the BSAF in Melanoides tuberculata was more than two for six metals, resulting in this species being classified as a macro-concentrator for $\mathrm{Mn}, \mathrm{Fe}, \mathrm{Cu}, \mathrm{Zn}, \mathrm{Cd}$, and $\mathrm{Pb}$ [64].

\section{Bioindication of Salt and Nutrients}

OSPW is generally dominated by sodium, chloride, bicarbonate, ammonium, and sometimes sulfate ions [49]. Leptoxis ampla was found to be sensitive to chloride with a LC50 (lethal concentration associated with 50\% mortality) value of $3414 \mu \mathrm{g} / \mathrm{L}$, which was the lowest LC50 value among four species reported, including two gastropod and two bivalve species [65]. Lymnaea stagnalis, at early developmental stages, was reported to be a very sensitive bioindicator of ammonia pollution [66]. An in situ evaluation in Canada has reported that tissues of lymnaeid snails collected from a natural pond exhibited lower trace element concentrations than those collected from microcosms where petroleum coke was used as sediment. However, the authors speculated that this might be due to the differences between the natural wetland and microcosms [67].

\section{Discussion}

From the literature review, Lymnaea stagnalis appears to be widely used to assess several toxicants associated with OSPW. The Lymnaea stagnalis Reproduction Test was adopted by the OECD (Organization for Economic Cooperation and Development) under its Guidelines for the Testing of Chemicals in 2016 [68]. However, mollusk toxicity evaluation is not emphasized in the biological test methods and guidance documents published by Environment Canada. Certain species of freshwater snails, such as Lymnaea stagnalis and Physa acuta, could be considered as standard toxicology model organisms in Canada. In addition, incorporating case studies using native snail species in field monitoring programs could address some concerns of Indigenous communities and other stakeholders about the potential long-term effects of oil sands activities. Overall, the literature supports the potential for aquatic snails to act as bioindicators of toxicity associated with OSPW exposure. Field-scale investigations with OSPW from different operators, in addition to laboratory testing focusing on OSPW-derived compounds (especially NAs), may be useful in further evaluating the utility of these organisms as bioindicators.

Table 1. Selected studies using freshwater snails in ecotoxicological assessments of analytes relevant to oil sands processaffected water (OSPW).

\begin{tabular}{|c|c|c|c|c|c|c|c|}
\hline Species (Family) & Age & $\begin{array}{l}\text { Chemical } \\
\text { Compounds }\end{array}$ & Effect & $\begin{array}{c}\text { Measured } \\
\text { Response } \\
\text { Type }\end{array}$ & $\begin{array}{c}\text { Exposure } \\
\text { Duration } \\
\text { (Days) }\end{array}$ & $\begin{array}{c}\text { Toxicological } \\
\text { Values } \\
(\mu \mathrm{g} / \mathrm{L})\end{array}$ & $\begin{array}{c}\text { Measured } \\
\text { Level in } \\
\text { OSPW } \\
(\mu \mathrm{g} / \mathrm{L})^{1} \\
\end{array}$ \\
\hline $\begin{array}{c}\text { Potamopyrgus } \\
\text { antipodarum } \\
\text { (Hydrobiidae) }\end{array}$ & $\mathrm{NR}^{3}$ & Cadmium & Mortality & LC50 & 2 & $\begin{array}{c}1000-4000 \\
\text { [69] }\end{array}$ & 1.6 \\
\hline $\begin{array}{l}\text { Somatogyrus sp. } \\
\text { (Hydrobiidae) }\end{array}$ & Adult & Potassium & $\begin{array}{l}\text { Ventilation/ } \\
\text { movement }\end{array}$ & EC50 & 4 & 7285 [70] & 12,000 \\
\hline
\end{tabular}


Table 1. Cont

\begin{tabular}{|c|c|c|c|c|c|c|c|}
\hline Species (Family) & Age & $\begin{array}{l}\text { Chemical } \\
\text { Compounds }\end{array}$ & Effect & $\begin{array}{c}\text { Measured } \\
\text { Response } \\
\text { Type }\end{array}$ & $\begin{array}{c}\text { Exposure } \\
\text { Duration } \\
\text { (Days) }\end{array}$ & $\begin{array}{c}\text { Toxicological } \\
\text { Values } \\
(\mu \mathrm{g} / \mathrm{L})\end{array}$ & $\begin{array}{c}\text { Measured } \\
\text { Level in } \\
\text { OSPW } \\
(\mu \mathrm{g} / \mathrm{L})^{1}\end{array}$ \\
\hline & Embryo & $\begin{array}{l}\text { Naphthenic } \\
\text { acids }\end{array}$ & $\begin{array}{c}\text { Embryonic } \\
\text { development }\end{array}$ & EC50 & 28 & 31,000 [37] & 53,000 \\
\hline & Embryo & Ammonia & Mortality & LC50 & 1 & $24,270[66]$ & 6400 \\
\hline & Juvenile & Silver & Growth & EC10 & 14 & $1.48[56]$ & 0.17 \\
\hline & Juvenile & Cadmium & Growth & EC10 & 14 & $12.0[56]$ & 1.6 \\
\hline & Juvenile & Copper & Growth & EC10 & 14 & $3.71[56]$ & 2.5 \\
\hline & Juvenile & Copper & Mortality & LC20 & 4 & 18 [53] & 2.5 \\
\hline & Juvenile & Nickel & Growth & EC10 & 14 & $115[56]$ & 120 \\
\hline & Juvenile & Lead & Growth & EC10 & 14 & $4.00[56]$ & 1.2 \\
\hline & Juvenile & Zinc & Growth & EC10 & 14 & $223[56]$ & 20 \\
\hline & $\mathrm{NR}^{3}$ & Mercury & Mortality & LC50 & 4 & $203.92[63]$ & 0.047 \\
\hline $\begin{array}{l}\text { Radix auricularia } \\
\text { (Lymnaeidae) }\end{array}$ & Embryo & Cadmium & $\begin{array}{c}\text { Embryonic } \\
\text { development }\end{array}$ & LC50 & 4 & $58.26[71]$ & 1.6 \\
\hline $\begin{array}{l}\text { Aplexa hypnorum } \\
\text { (Physidae) }\end{array}$ & Adult & Acenaphthene & Mortality & LC50 & 4 & $>2040$ [72] & $<0.11$ \\
\hline \multirow{2}{*}{$\begin{array}{c}\text { Physa gyrina } \\
\text { (Physidae) }\end{array}$} & Adult & Naphthalene & Mortality & LC50 & 2 & 5020 [73] & $<0.075$ \\
\hline & Immature & Cadmium & Mortality & $\mathrm{TL}^{2} 0^{2}$ & 4 & $430[54]$ & 1.6 \\
\hline $\begin{array}{c}\text { Biomphalaria } \\
\text { glabrata } \\
\text { (Planorbidae) }\end{array}$ & Embryo & Chromium & $\begin{array}{c}\text { Embryonic } \\
\text { development }\end{array}$ & EC50 & 1 & 5760 [25] & 4.4 \\
\hline $\begin{array}{l}\text { Leptoxis ampla } \\
\text { (Pleuroceridae) }\end{array}$ & Juvenile & Chloride & Mortality & LC50 & 4 & 3414 [65] & 139,000 \\
\hline
\end{tabular}

${ }^{1}$ Median values were derived from Table $6-1$ of reference $[49] ;{ }^{2}$ TL50 $=50 \%$ tolerance limits; ${ }^{3} \mathrm{NR}=$ not reported.

Author Contributions: Conceptualization, Z.C., J.D. and B.E.; writing-original draft preparation, Z.C.; writing-review and editing, B.E. and J.D.; supervision, B.E.; project administration, Z.C.; funding acquisition, Z.C., J.D., and B.E. All authors have read and agreed to the published version of the manuscript.

Funding: This research was funded by InnoTech Alberta, internal proposal number EPS-2019-IN-009. This research received no external funding.

Conflicts of Interest: The authors declare no conflict of interest.

\section{References}

1. Hatfield Consultants. Ecotoxicity Assessment of Treated Oil Sands Process-Affected Water (OSPW): 2019 Toxicity and Mesocosms Studies. Government of Alberta, Ministry of Environment and Parks. 2019. Available online: Open.alberta.ca/publications/9781 460144503 (accessed on 20 October 2020).

2. Bauer, A.E.; Hewitt, L.M.; Parrott, J.L.; Bartlett, A.J.; Gillis, P.L.; Deeth, L.E.; Rudy, M.D.; Vanderveen, R.; Brown, L.; Campbell, S.D.; et al. The toxicity of organic fractions from aged oil sands process-affected water to aquatic species. Sci. Total Environ. 2019, 669, 702-710. [CrossRef] [PubMed]

3. Li, C.; Fu, L.; Stafford, J.; Belosevic, M.; Gamal El-Din, M. The toxicity of oil sands process-affected water (OSPW): A critical review. Sci. Total Environ. 2017, 601-602, 1785-1802. [CrossRef] [PubMed]

4. Martin, J.W. The Challenge: Safe release and reintegration of oil sands process-affected water. Environ. Toxicol. Chem. 2015, 34, 2682. [CrossRef] [PubMed]

5. Tanna, R.N.; Redman, A.D.; Frank, R.A.; Arciszewski, T.J.; Zubot, W.A.; Wrona, F.J.; Brogly, J.A.; Munkittrick, K.R. Overview of existing science to inform oil sands process water release: A technical workshop summary. Integr. Environ. Assess. Manag. 2019, 15, 519-527. [CrossRef] [PubMed]

6. Scott, A.C.; Zubot, W.; Davis, C.W.; Brogly, J. Bioaccumulation potential of naphthenic acids and other ionizable dissolved organics in oil sands process water (OSPW)-A review. Sci. Total Environ. 2020, 712, 134558. [CrossRef]

7. Meshref, M.N.A.; Chelme-Ayala, P.; Gamal El-Din, M. Fate and abundance of classical and heteroatomic naphthenic acid species after advanced oxidation processes: Insights and indicators of transformation and degradation. Water Res. 2017, 125, 62-71. [CrossRef]

8. Holt, E.A.; Miller, S.W. Bioindicators: Using organisms to measure environmental impacts. Nat. Educ. Knowl. 2011, 2, 1-8.

9. Asif, N.; Malik, M. A review of on environmental pollution bioindicators. Pollution 2018, 4, 111-118. [CrossRef] 
10. Strong, E.E.; Gargominy, O.; Ponder, W.F.; Bouchet, P. Global diversity of gastropods (Gastropoda; Mollusca) in freshwater. Hydrobiologia 2008, 595, 149-166. [CrossRef]

11. Maher, B.; Kumar, A.; Taylor, A.; Chariton, A.; Pettigrove, V.; Baird, D.; Adams, M.; Spadaro, D.; Hook, S. Sediment Quality Assessment-A Practical Guide; Simpson, S., Batley, G., Eds.; CSIRO Publishing: Clayton South, Australia, 2016 ; p. 89.

12. Bouétard, A.; Côte, J.; Besnard, A.L.; Collinet, M.; Coutellec, M.A. Environmental versus anthropogenic effects on population adaptive divergence in the freshwater snail Lymnaea stagnalis. PLoS ONE 2014, 9, e106670. [CrossRef]

13. Bandow, C.; Weltje, L. Development of an embryo toxicity test with the pond snail Lymnaea stagnalis using the model substance tributyltin and common solvents. Sci. Total Environ. 2012, 435-436, 90-95. [CrossRef] [PubMed]

14. El-Khayat, H.M.; Hamid, H.A.; Gaber, H.S.; Mahmoud, K.M.; Flefel, H.E. Snails and fish as pollution biomarkers in Lake Manzala and laboratory A: Lake Manzala snails. Fish. Aquac. J. 2015, 6, 1-9. [CrossRef]

15. Stankovic, S.; Kalaba, P.; Stankovic, A.R. Bioindicators of Toxic Metals. Environ. Chem. Lett. 2014, 12, 63-84. [CrossRef]

16. Markert, B.A.; Breure, A.M.; Zechmeister, H.G. Chapter 1 Definitions, strategies and principles for bioindication/biomonitoring of the environment. In Trace Metals and Other Contaminants in the Environment; Elsevier Science: Amsterdam, The Netherlands, 2003; Volume 6, pp. 3-39. [CrossRef]

17. Parmar, T.K.; Rawtani, D.; Agrawal, Y.K. Bioindicators: The natural indicator of environmental pollution. Front. Life Sci. 2016, 9, 110-118. [CrossRef]

18. Reguera, P.; Couceiro, L.; Fernández, N. A review of the empirical literature on the use of limpets Patella spp. (Mollusca: Gastropoda) as bioindicators of environmental quality. Ecotoxicol. Environ. Saf. 2018, 148, 593-600. [CrossRef]

19. Oliveira-Filho, E.C.; Nakano, E.; Tallarico, L.D.F. Bioassays with freshwater snails Biomphalaria sp.: From control of hosts in public health to alternative tools in ecotoxicology. Invertebr. Reprod. Dev. 2017, 61, 49-57. [CrossRef]

20. Delfina, M.R.; Tapfuma, D.; Mnkandla, S.; Basopo, N. Toxicological effects of differently polluted dam waters spiked with pesticides on freshwater snails Lymnaea Natalensis. Int. J. Chem. 2016, 8, 1. [CrossRef]

21. Habib, M.R.; Mohamed, A.H.; Osman, G.Y.; Mossalem, H.S.; Sharaf El-Din, A.T.; Croll, R.P. Biomphalaria alexandrina as a bioindicator of metal toxicity. Chemosphere 2016, 157, 97-106. [CrossRef]

22. Campoy-Diaz, A.D.; Arribére, M.A.; Guevara, S.R.; Vega, I.A. Bioindication of mercury, arsenic and uranium in the apple snail Pomacea canaliculata (Caenogastropoda, Ampullariidae): Bioconcentration and depuration in tissues and symbiotic corpuscles. Chemosphere 2018, 196, 196-205. [CrossRef]

23. Oehlmann, J.; Schulte-Oehlmann, U. Chapter 17 Molluscs as bioindicators. In Trace Metals and Other Contaminants in the Environment (Bioindicators and Biomonitors); Elsevier Science: Amsterdam, The Netherlands, 2003; Volume 6, pp. 577-635. [CrossRef]

24. Tallarico, L.D.F. Freshwater gastropods as a tool for ecotoxicology assessments in Latin America. Am. Malacol. Bull. 2015, 33, 330-336. [CrossRef]

25. Tallarico, L.D.F.; Borrely, S.I.; Hamada, N.; Grazeffe, V.S.; Ohlweiler, F.P.; Okazaki, K.; Granatelli, A.T.; Pereira, I.W.; de Bragança Pereira, C.A.; Nakano, E. Developmental toxicity, acute toxicity and mutagenicity testing in freshwater snails Biomphalaria glabrata (Mollusca: Gastropoda) exposed to chromium and water samples. Ecotoxicol. Environ. Saf. 2014, 110, 208-215. [CrossRef] [PubMed]

26. Pirger, Z.; Zrinyi, Z.; Maász, G.; Molnár, É.; Kiss, T. Pond Snail Reproduction as Model in the Environmental Risk Assessment: Reality and Doubts; Ray, S., Ed.; IntechOpen: London, UK, 2018; Volume 2, pp. 33-53. [CrossRef]

27. Amorim, J.; Abreu, I.; Rodrigues, P.; Peixoto, D.; Pinheiro, C.; Saraiva, A.; Carvalho, A.P.; Guimarães, L.; Oliva-Teles, L. Lymnaea stagnalis as a freshwater model invertebrate for ecotoxicological studies. Sci. Total Environ. 2019, 669, 11-28. [CrossRef] [PubMed]

28. McQueen, A.D.; Kinley, C.M.; Hendrikse, M.; Gaspari, D.P.; Calomeni, A.J.; Iwinski, K.J.; Castle, J.W.; Haakensen, M.C.; Peru, K.M.; Headley, J.V.; et al. A risk-based approach for identifying constituents of concern in oil sands process-affected water from the Athabasca Oil Sands region. Chemosphere 2017, 173, 340-350. [CrossRef] [PubMed]

29. Redman, A.D.; Butler, J.D.; Letinski, D.J.; Di Toro, D.M.; Leon Paumen, M.; Parkerton, T.F. Technical basis for using passive sampling as a biomimetic extraction procedure to assess bioavailability and predict toxicity of petroleum substances. Chemosphere 2018. [CrossRef]

30. Redman, A.D.; Parkerton, T.F.; Butler, J.D.; Letinski, D.J.; Frank, R.A.; Hewitt, L.M.; Bartlett, A.J.; Gillis, P.L.; Marentette, J.R.; Parrott, J.L.; et al. Application of the target lipid model and passive samplers to characterize the toxicity of bioavailable organics in oil sands process-affected water. Environ. Sci. Technol. 2018, 52, 8039-8049. [CrossRef] [PubMed]

31. Hedgpeth, B.M.; Redman, A.D.; Alyea, R.A.; Letinski, D.J.; Connelly, M.J.; Butler, J.D.; Zhou, H.; Lampi, M.A. Analysis of sublethal toxicity in developing zebrafish embryos exposed to a range of petroleum substances. Environ. Toxicol. Chem. 2019, 38, 1302-1312. [CrossRef] [PubMed]

32. Bartlett, A.J.; Frank, R.A.; Gillis, P.L.; Parrott, J.L.; Marentette, J.R.; Brown, L.R.; Hooey, T.; Vanderveen, R.; McInnis, R.; Brunswick, P.; et al. Toxicity of naphthenic acids to invertebrates: Extracts from oil sands process-affected water versus commercial mixtures. Environ. Pollut. 2017, 227, 271-279. [CrossRef]

33. Mahaffey, A.; Dubé, M. Review of the composition and toxicity of oil sands process-affected water. Environ. Rev. 2016, 25, 97-114. [CrossRef]

34. Clemente, J.S.; Fedorak, P.M. A review of the occurrence, analyses, toxicity, and biodegradation of naphthenic acids. Chemosphere 2005, 60, 585-600. [CrossRef] 
35. John Cairns, J.; Scheier, A. The effects of temperature and water hardness upon the toxicity of naphthenic acids to the common bluegill sunfish, Lepomis macrochirus Raf., and the pond snail, Physa heterostropha Say. Not. Nat. 1962, 353, 1-12.

36. Johnston, C.U. Toxicology of Model Naphthenic Acids in the Great Pond Snail. Master's Thesis, University of Calgary, Calgary, AB, Canada, 2015.

37. Johnston, C.U.; Clothier, L.N.; Quesnel, D.M.; Gieg, L.M.; Chua, G.; Hermann, P.M.; Wildering, W.C. Embryonic exposure to model naphthenic acids delays growth and hatching in the pond snail Lymnaea Stagnalis. Chemosphere 2017, 168, 1578-1588. [CrossRef] [PubMed]

38. Marentette, J.R.; Frank, R.A.; Bartlett, A.J.; Gillis, P.L.; Hewitt, L.M.; Peru, K.M.; Headley, J.V.; Brunswick, P.; Shang, D.; Parrott, J.L. Toxicity of naphthenic acid fraction components extracted from fresh and aged oil sands process-affected waters, and commercial naphthenic acid mixtures, to fathead minnow (Pimephales promelas) embryos. Aquat. Toxicol. 2015, 164, 108-117. [CrossRef] [PubMed]

39. Mazur, R.; Wagner, A.; Zhou, M. The application of the Lymnaea stagnalis embryo-test in the toxicity bioindication of surfactants in fresh waters. Ecol. Indic. 2013, 30, 190-195. [CrossRef]

40. Headley, J.V.; McMartin, D.W. A review of the occurrence and fate of naphthenic acids in aquatic environments. J. Environ. Sci. Heal. Part A Toxic/Hazardous Subst. Environ. Eng. 2004, 39, 1989-2010. [CrossRef]

41. Ross, M.S.; Pereira, A.D.S.; Fennell, J.; Davies, M.; Johnson, J.; Sliva, L.; Martin, J.W. Quantitative and qualitative analysis of naphthenic acids in natural waters surrounding the canadian oil sands industry. Environ. Sci. Technol. 2012, 46, 12796-12805. [CrossRef]

42. Scott, A.C.; Young, R.F.; Fedorak, P.M. Comparison of GC-MS and FTIR methods for quantifying naphthenic acids in water samples. Chemosphere 2008, 73, 1258-1264. [CrossRef]

43. Grewer, D.M.; Young, R.F.; Whittal, R.M.; Fedorak, P.M. Naphthenic acids and other acid-extractables in water samples from Alberta: What is being measured? Sci. Total Environ. 2010, 408, 5997-6010. [CrossRef]

44. Wayland, M.; Headley, J.V.; Peru, K.M.; Crosley, R.; Brownlee, B.G. Levels of polycyclic aromatic hydrocarbons and dibenzothiophenes in wetland sediments and aquatic insects in the oil sands area of Northeastern Alberta, Canada. Environ. Monit. Assess. 2008, 136, 167-182. [CrossRef]

45. Spehar, R.L.; Poucher, S.; Brooke, L.T.; Hansen, D.J.; Champlin, D.; Cox, D.A. Comparative toxicity of fluoranthene to freshwater and saltwater species under fluorescent and ultraviolet light. Arch. Environ. Contam. Toxicol. 1999, 37, 496-502. [CrossRef]

46. Karlsson, M. Analysis of Polycyclic Aromatic Hydrocarbons in Freshwater Snails of Family Lymnaeidae from Patholmsviken. Independent Thesis, Orebro University, Örebro, Sweden, 2015.

47. Osman, G.; Galal, M.; Abul-Ezz, A.; Ahmad, M.; Abul-Ela, M.; Hegazy, A.M. Polycyclic aromatic hydrocarbons (PAHs) accumulation and histopathological biomarkers in gills and mantle of Lanistes carinatus (Molluscs, Ampullariidae) to assess crude oil toxicity. Punjab Univ. J. Zool. 2017, 32, 39-50.

48. Ololade, I.A.; Oladoja, N.A.; Ololade, O.O.; Saliu, T.D.; Alabi, A.B.; Obadawo, S.B.; Anifowose, M.M. Bioaccumulation and toxic potencies of polycyclic aromatic hydrocarbons in freshwater biota from the Ogbese River, Nigeria. Environ. Monit. Assess. 2021, 193, 8. [CrossRef] [PubMed]

49. Hrynyshyn, J. End Pit Lakes Guidance Document; Cumulative Environmental Management Association: 2012. Available online: https:/ / www.cclmportal.ca/resource/end-pit-lakes-guidance-document-2012 (accessed on 18 October 2020).

50. Erben, R.; Pisl, Z. Acute toxicity for some evaporating aromatic hydrocarbons for freshwater snails and crustaceans. Int. Rev. ges. Hydrobiol. 1993, 78, 161-167. [CrossRef]

51. Zheng, S.; Wang, Y.; Zhou, Q.; Chen, C. Responses of oxidative stress biomarkers and DNA damage on a freshwater snail (Bellamya aeruginosa) stressed by ethylbenzene. Arch. Environ. Contam. Toxicol. 2013, 65, 251-259. [CrossRef]

52. Ali, H.; Khan, E.; Ilahi, I. Environmental chemistry and ecotoxicology of hazardous heavy metals: Environmental persistence, toxicity, and bioaccumulation. J. Chem. 2019, 2019, 1-14. [CrossRef]

53. Ng, T.Y.T.; Pais, N.M.; Wood, C.M. Mechanisms of waterborne Cu toxicity to the pond snail Lymnaea stagnalis: Physiology and Cu bioavailability. Ecotoxicol. Environ. Saf. 2011, 74, 1471-1479. [CrossRef]

54. Wier, C.F.; Walter, W.M. Toxicity of cadmium in the freshwater snail, Physa gyrina Say. J. Environ. Qual. 1976, 5, 359-362. [CrossRef]

55. Salánki, J.; Farkas, A.; Kamardina, T.; Rózsa, K.S. Molluscs in biological monitoring of water quality. Toxicol. Lett. 2003, 140-141, 403-410. [CrossRef]

56. Crémazy, A.; Brix, K.V.; Wood, C.M. Chronic toxicity of binary mixtures of six metals (Ag, Cd, Cu, Ni, Pb, and Zn) to the great pond snail Lymnaea stagnalis. Environ. Sci. Technol. 2018, 52, 5979-5988. [CrossRef]

57. Crémazy, A.; Brix, K.V.; Wood, C.M. Using the Biotic Ligand Model framework to investigate binary metal interactions on the uptake of Ag, Cd, Cu, Ni, Pb and Zn in the freshwater snail Lymnaea stagnalis. Sci. Total Environ. 2019, 647, 1611-1625. [CrossRef]

58. Despotović, S.G.; Prokić, M.D.; Gavrić, J.P.; Gavrilović, B.R.; Radovanović, T.B.; Borković-Mitić, S.S.; Pavlović, S.Z.; Saičić, Z.S. Evaluation of the river snail Viviparus acerosus as a potential bioindicator species of metal pollution in freshwater ecosystems. Arch. Biol. Sci. 2019, 71, 39-47. [CrossRef]

59. Gomot, A. Toxic effects of cadmium on reproduction, development, and hatching in the freshwater snail Lymnaea stagnalis for water quality monitoring. Ecotoxicol. Environ. Saf. 1998, 297, 288-297. [CrossRef] [PubMed]

60. Mahmoud, K.M.A.; Abu Taleb, H.M.A. Fresh water snails as bioindicator for some heavy metals in the aquatic environment. Afr. J. Ecol. 2013, 51, 193-198. [CrossRef] 
61. Wadaan, M.A.M. The fresh water growing snail Physa acuta: A suitable bioindicator for testing cadmium toxicity. Saudi J. Biol. Sci. 2007, 40, 185-190.

62. Osman, G.; Mohamed, A.; Abdel Kader, A.; Gharieb, M.; Abdel-Motlb, A. Physa acuta snail as a biomonitor for the efficacy of bioremediation treatment of heavy metals (Fe III and Cd II) using the fungus (Eupenicillium lapidosum) in lined and unlined laboratory conditions. Egypt. J. Aquat. Biol. Fish. 2018, 22, 201-218. [CrossRef]

63. Kayange, I.A. Use of Snails as Bioindicators of Mercury Pollution in Aquatic Ecosystems. Master's Thesis, Sokoine Univeristy of Agriculture, Morogoro, Tanzania, 2013.

64. Orabi, O.; Khalifa, M.M. Biota sediment accumulation and bioconcentration factors of trace metals in the snail Melanoides tuberculata form the agricultural drains of the Manzala Lagoon, Egypt. Environ. Sci. Pollut. Res. 2020, 27, 17754-17761. [CrossRef]

65. Gibson, K.J. Acute Toxicity Testing on Freshwater Mussels (Bivalvia: Unionidae) and Freshwater Snails (Gastropoda: Caenogastropoda). Master's Thesis, Troy University, Troy, AL, USA, 2015.

66. Mazur, R.; Shubiao, W.; Szoszkiewicz, K.; Bedla, D.; Nowak, A. A Lymnaea stagnalis embryo test for toxicity bioindication of acidification and ammonia pollution in water. Water 2016, 8, 295. [CrossRef]

67. Baker, L.F.; Ciborowski, J.J.H.; MacKinnon, M.D. Petroleum coke and soft tailings sediment in constructed wetlands may contribute to the uptake of trace metals by algae and aquatic invertebrates. Sci. Total Environ. 2012, 414, 177-186. [CrossRef]

68. OECD. OECD Guideline for the Testing of Chemicals Test. No. 243: Lymnaea Stagnalis Reproduction Test.; Section 2; OECD Publishing: Paris, France, 2016; Available online: https:/ / www.oecd-ilibrary.org/environment/test-no-243-lymnaea-stagnalis-reproductiontest_9789264264335-en (accessed on 4 March 2020).

69. Moller, V.; Forbes, V.E.; Depledg, M.H. Influence of acclimation and exposure temperature on the acute toxicity of cadmium to the freshwater snail Potamopyrgus antipodarum (hydrobiidae). Environ. Toxicol. Chem. 1994, 13, 1519-1524. [CrossRef]

70. Gibson, K.J.; Miller, J.M.; Johnson, P.D.; Stewart, P.M. Acute toxicity of chloride, potassium, nickel, and zinc to federally threatened and petitioned mollusk species. Southeast. Nat. 2018, 17, 239-256. [CrossRef]

71. Liu, T.; Koene, J.M.; Dong, X.; Fu, R. Sensitivity of isolated eggs of pond snails: A new method for toxicity assays and risk assessment. Environ. Monit. Assess. 2013, 185, 4183-4190. [CrossRef]

72. Holcombe, G.W.; Phipps, G.L.; Fiandt, J.T. Toxicity of selected priority pollutants to various aquatic organisms. Ecotoxicol. Environ. Saf. 1983, 7, 400-409. [CrossRef]

73. Millemann, R.E.; Birge, W.J.; Black, J.A.; Cushman, R.M.; Daniels, K.L.; Franco, P.J.; Giddings, J.M.; McCarthy, J.F.; Stewart, A.J. Comparative acute toxicity to aquatic organisms of components of coal-derived synthetic fuels. Trans. Am. Fish. Soc. 1984, 113, 74-85. [CrossRef] 